\title{
Tourism and Income in Greece: A Market Solution to the Debt Crisis ${ }^{1}$
}

\author{
By Henry Thompson*
}

The tourism industry is showing increased income due to specialization and trade offers Greece the solution to its sovereign debt crisis. Opening the economy to investment and competition, not only in tourism but across all sectors, would raise income and relieve the burden of paying the government debt. This paper assesses the potential of tourism to lead the transformation of Greece into a competitive economy.

Tourism has steadily grown in Greece over recent decades due to rising incomes worldwide, declining travel cost, and steady investment by the industry. Tourism is showing that moving toward a competitive market economy could raise income and relieve the taxpayer burden of government debt. The present paper evaluates the expanding tourism industry and its potential to influence the rest of the economy.

Tourism is an expanding global industry critical to economic growth in a number of countries. The literature on tourism and growth documents this potential especially among developing countries. The situation of Greece is different in that it is a developed country in the European Union. Greece faces a number of well known structural challenges based on the inefficient legal system, archaic labor laws, restricted international investment, burdensome income and sales tax rates, a weak property tax system, and corrupt government. While the tourism industry has the potential to continue raising income, more critically it illustrates the gains from open market competition, specialization, and trade.

The first section presents a brief history of the debt crisis in Greece followed by sections on the tourism sector, its relation to the economy, and macroeconomic issues related to tourism.

\section{The Government Debt Crisis}

Greece fell into crisis following decades of government deficit due to wasteful spending and the ineffective tax system. The government financed its overly generous pension system creating money supply leading to inflation and devaluation. From the early 1980s to euro entry in 2001 the drachma depreciated $1200 \%$. Continuing this inflation rate, the drachma would have fallen from 350 to 5,000 by 2016 .

\footnotetext{
${ }^{*}$ Professor, Auburn University, USA.

1 Thanks for suggestions and comments go to Gregory Papanikos, Dimitris Thomakos, Christos Petreas, Thomas Alexopoulos, and Constantina Kottaridi.
} 
Switching to the euro in 2001 the government borrowed to continue spending. Facing Euro Zone limits on debt, the government understated the level of debt based on interest and exchange rate projections. The crisis began in 2008 when scheduled balloon payments were missed and the debt was revealed to be well beyond the Euro Zone limit.

Households and firms began hoarding expecting default and return to the drachma. Bank deposits moved out of the country to safe havens beyond the reach of increasing efforts at tax collection. Investment declined, foreign investment almost disappearing. The new government closed the banks in 2008 and instituted restrictions on bank account withdrawals.

The level of government debt represents a perpetual interest payment of $4 \%$ of current income. Paying that debt down would require that much more of income for a generation. If nothing else, Greece provides an example of wasteful deficit spending. Euro Zone supervision has forced the government to become more efficient. The budget has balanced although balloon debt payments are financed by publicized bailouts in a slow restructuring process.

Greeks are successful in business, along the shores of the Mediterranean through history and now spread over Europe, North America, and Australia. There were episodes of sustained economic growth following independence from the Ottomans during the late 1800s, between the two world wars, and during the 1950s following the civil war.

The civil war between communists supported by the Soviet Union and conservatives supported by the west left scars that still divide the country. The communists lost but continued their political efforts, and gained influence during the crisis. The wide political spectrum runs from communism to right wing military. The two extremes oddly became the ruling coalition during 2015. There are numerous political parties with new ones appearing and others fading based on personalities as well as ideologies.

In the late 1970s the government took a turn toward Eastern bloc socialism following a failed military government. The government nationalized major industries including shipyards, mining, refining, utilities, airlines, banks, manufacturing, and hospitals. The ensuing lack of investment and increased labor union influence degraded the economy. The popular but unsustainable pension system was financed by money creation. The drachma lost over $90 \%$ of its value by the dawn of the euro in 2001 .

Labor unions and public sector strikes have strong negative effects. The private sector is constrained by a job tenure law. Labor market practice largely explains the complete lack of multinational activity.

In 2015 the government threatened default in a tragicomedy that eliminated any credibility it might have had. Banks are hampered by mandatory purchase of government bonds and "capital control" limits on withdrawals, transfers, and new accounts. The failed tax system is based on prohibitive sales and income tax rates leading to endemic tax avoidance. Routine corruption and crony capitalism characterize government operation.

The economy of Greece is based on natural resources and location. Agriculture and mining remain successful. Small scale manufacturing mostly 
processes natural resource products. The successful merchant marine, foreign flagged due to the high tax rates, is based on a history of seafaring. Ports linking to Europe have recently improved with foreign investment. The transport industry enjoys growing demand. Pipelines for natural gas run through the country. Tourism too has its basis in natural resources including climate, beaches, and mountains.

\section{The Tourism Market in Greece}

Tourism is market exchange with travel from the source to the host country for goods and services. Tourism is a large share of the typical consumer budget and requires substantial investment by the host. The tourism market in Greece is competitive although foreign investment is constrained.

The exchange rate affects the price of tourism. While the drachma regularly depreciated, the euro appreciates following the German mark. Euro appreciation raises the price of tourism in Greece for those outside the Zone.

Steadily rising income has been the source of tourism growth during recent decades. Travel costs have also fallen contributing to increased demand. On the supply side, investment has steadily increased in Greece as workers from Central and Eastern Europe keep costs low.

Figure 1 shows evidence of expanding tourism. All of the present data is from the World Trade Organization and Eurostat. Quantity Q is the number of arrivals in millions. Reported revenue $\mathrm{R}$ leads to the derived average price $\mathrm{P}$. Both $\mathrm{Q}$ and $\mathrm{R}$ have trended upward over the last two decades. The 2004 Olympics had no impact as verified by Kasimati and Dawson (2009). The decrease in 2009 at the onset of the crisis is apparent. The pattern in price $\mathrm{P}$ is similar, peaking at the onset of the crisis. Over the two decades, the rising $\mathrm{P}$ and $\mathrm{Q}$ reflect a net increase in demand.

Figure 1. Tourism Quantity, Price, Revenue

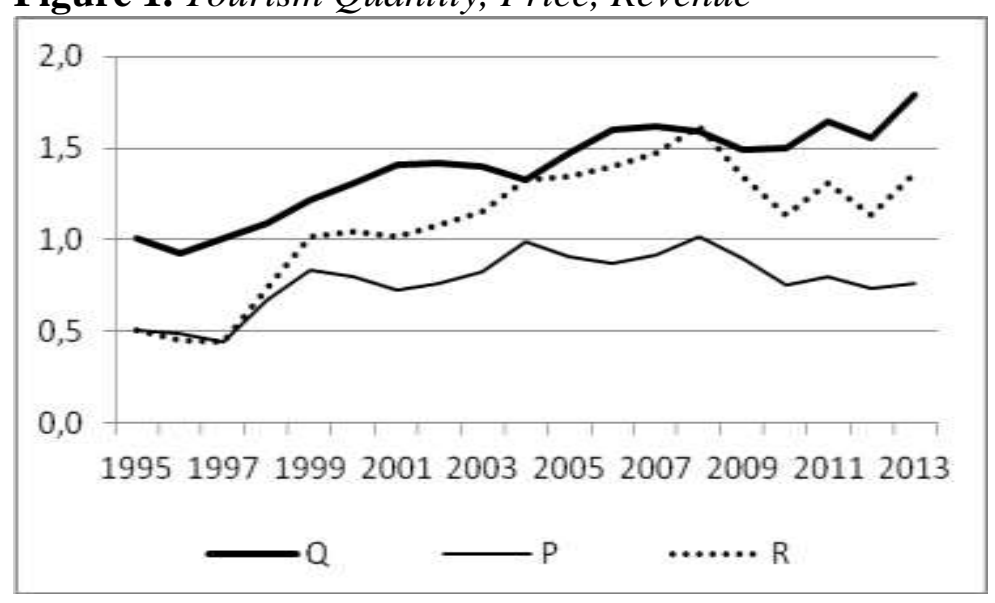

Changes in $\mathrm{P}$ and $\mathrm{Q}$ in Figure 2 indicate whether a net change in supply or demand dominate the market. Increases in both indicate a net increase in 
demand, decreases in both a net decrease. A decrease in $\mathrm{P}$ and increase in $\mathrm{Q}$ indicate a net increase in supply, and the opposite a decrease in supply. Six years are characterized by increased demand and six others by increased supply. Momentum is noticeable with changes in the same direction for a few years. The changes are large, typically on the order of $10 \%$.

Figure 2. Percentage Changes in Tourism $Q$ and $P$

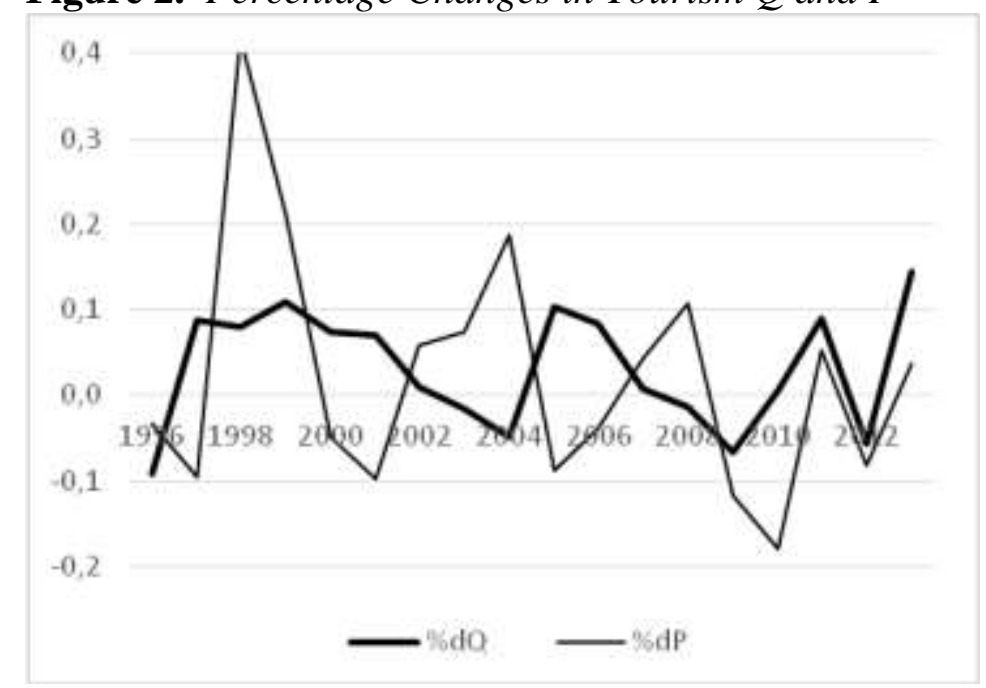

Figure 3 shows the scale of market adjustments. Increases in Q along the horizontal axis are larger than decreases. The same is true for changes in $\mathrm{P}$ along the vertical axis. The predominant effect is increased demand with the largest effects in the upper right quadrant. Increased supply in the lower right quadrant leads to large output increases. The much smaller effects of the three years of decreased demand are in the lower left and the three years of decreased supply in the upper left.

Figure 3. Scatter of Percentage Changes

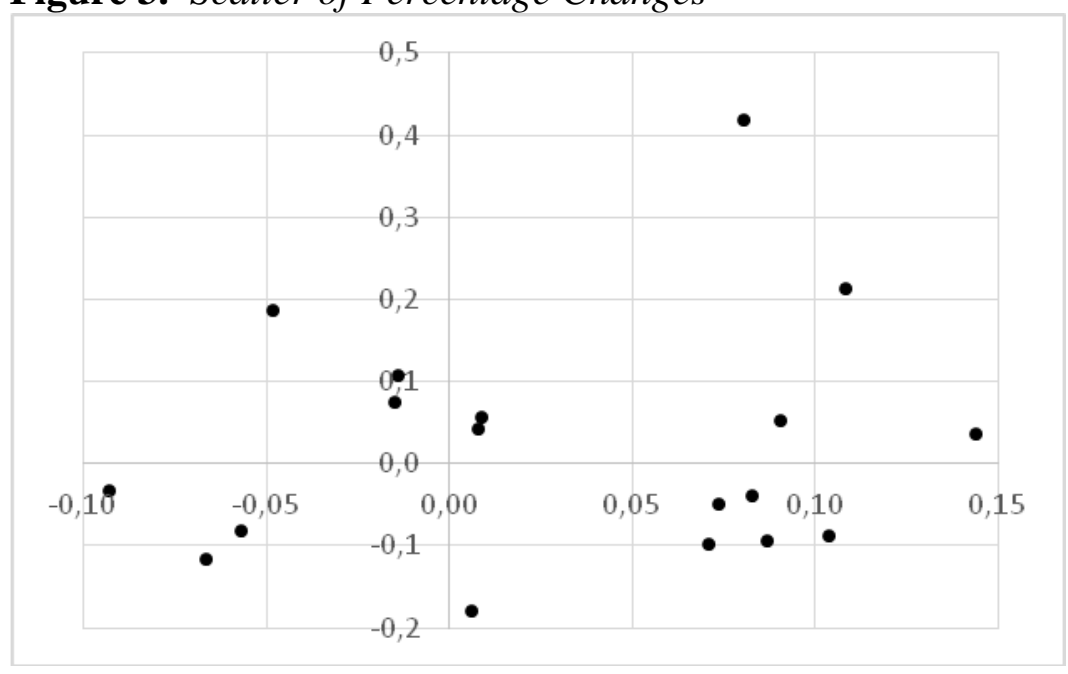


The growing tourism market presents a source of tax revenue. The $23 \%$ sales tax falls on tourists due to inelastic demand. The prohibitive $43 \%$ income tax rate leads to unreported income. Both sales and income taxes are difficult to collect due to endemic tax avoidance. The government should replace these inefficient taxes with property taxes on tourism assets as suggested by Papanikos (2015a). Opening to foreign investment would broaden the tax base and shift the tax burden toward foreign stockholders.

\section{Economic Adjustments to Expanding Tourism}

Specialization and trade would diminish import competing industries but expand export industries. Export industries include agriculture, mining, business services, finance, communications, and shipping as well as tourism. The production frontier PF in Figure 4 shows the maximum outputs the economy can produce separating tourism and other export industries $\mathrm{X}$ from import competing industries M. The dotted indifference curves IC indicate consumer preferences.

Figure 4. Gains from Trade

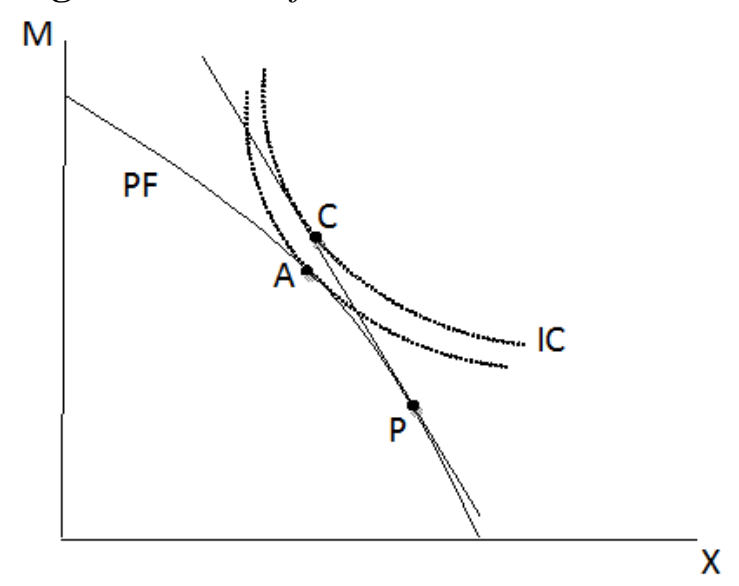

The economy on its own would produce and consume at point $\mathrm{A}$ on the highest indifference curve it can reach. A rising price of tourism moves the economy to produce more $\mathrm{X}$ and less $\mathrm{M}$ to point $\mathrm{P}$ where tt indicates the terms of trade. Expanding export industries offer higher wages to attract labor. The economy consumes on the tt line trading $\mathrm{X}$ for $\mathrm{M}$. Consumers enjoy $\mathrm{C}$ on the higher indifference curve. Trade is good news for the export sector but bad news for industries that cannot compete.

Figure 5 shows the trend toward specialization in tourism since 1975. The winners with trade are owners of capital in the export industries, while owners of capital in the import competing industries lose. Labor gains as it moves toward higher wages in the export industries. 
Figure 5. Long Term Tourism Revenue

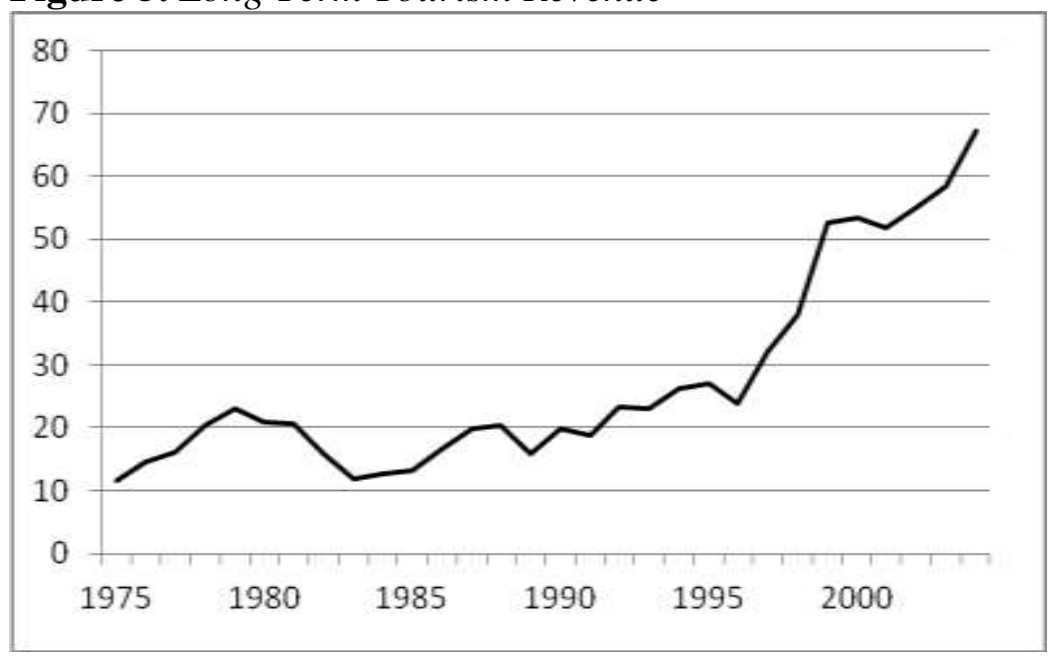

Figure 6 shows the history of growing sectors with shares of Gross Domestic Product GDP. The Retail sector includes retail and wholesale business as well as the restaurants, hotels, and other tourism services. Retail accounts for about a quarter of the economy.

Figure 6. Trade, Communication, Finance, Real Estate, Public Administration

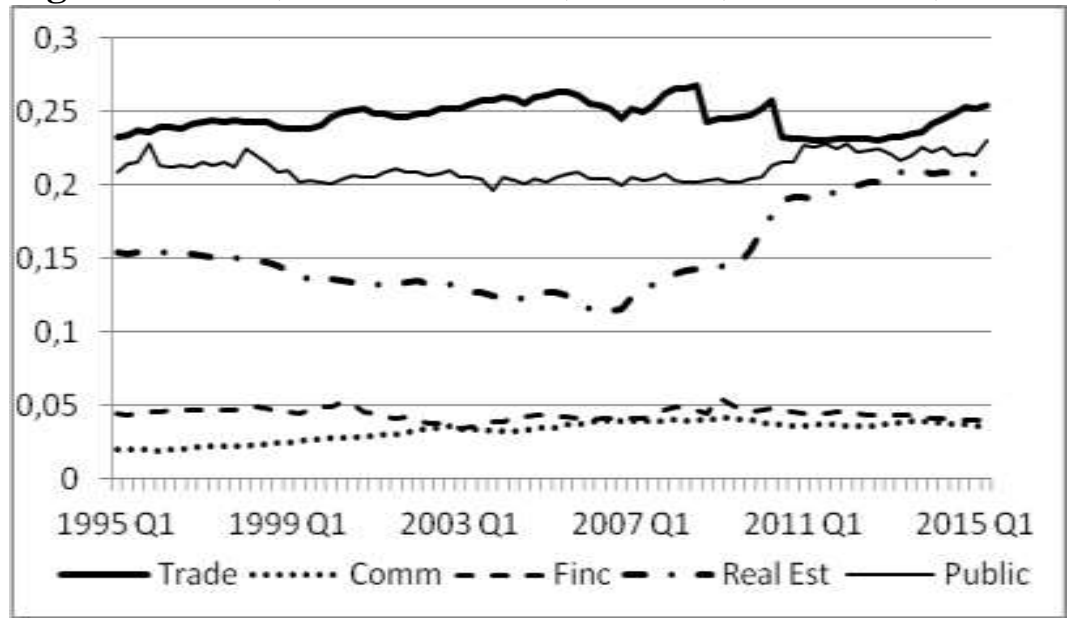

Public Administration accounts for almost a quarter of the economy as well, a share that has grown during the crisis. Real Estate expanded to over $20 \%$ due to forced property sales with new property taxes. The recently completed registry resulted claims of property that had been tax free.

Finance and Communications have been slightly increasing, each about $5 \%$ of GDP. Finance is regulated and uncompetitive, while Communications is open and competitive.

Figure 7 shows industries that have lost shares of GDP. Manufacturing has declined by about one third to $10 \%$ of the GDP. Professionals have declined slightly although income is underreported. Construction has declined since 
2007 due to falling income and rising property taxes. Agriculture was declining up to 2007 but more recently has grown due to improving quality and branding.

Figure 7. Agriculture, Construction, Manufacturing, Professional

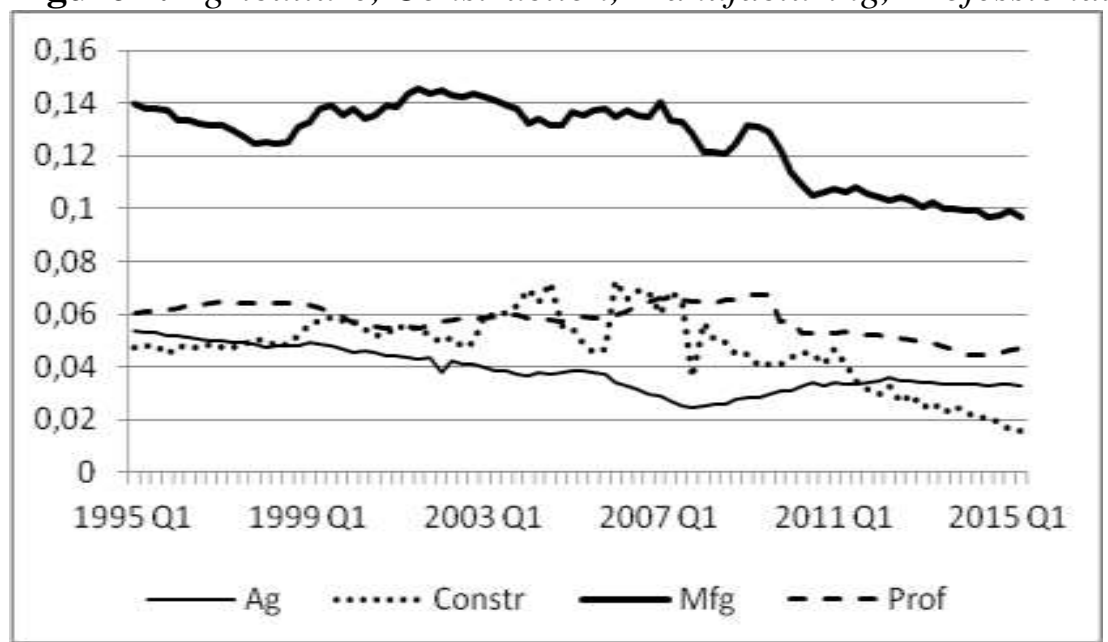

Wages depend on productivity and output prices. Productivity primarily depends on investment focused in export industries raising labor demand. Thompson (2016) explores the possible effects of expanding tourism on wages in general equilibrium. Figure 8 reports the average wage had an upward trend until the crisis. Expanding export industries have to bid for labor. As labor moves into export production, labor supply in the rest of the economy falls resulting in higher wages throughout the economy. In contrast, legislated wage increases ultimately have no effect. While minimum and union wages raise wages of those with jobs, others are squeezed out of that market.

\section{Figure 8. Average Wage}

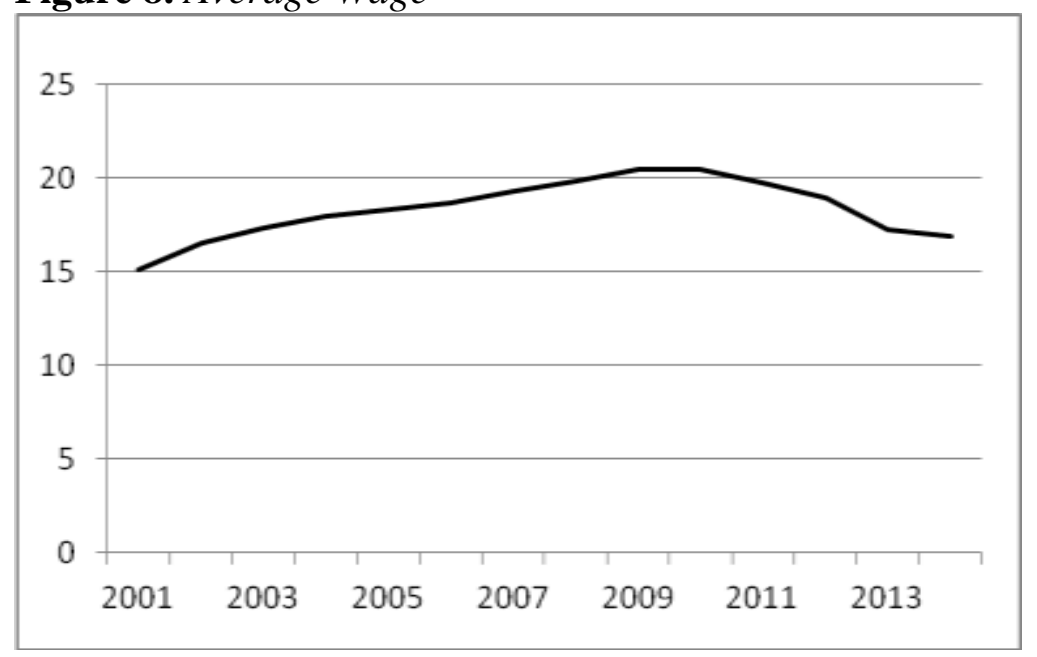

Immigration increases labor supply and lowers the wage. Immigrants are mainly less skilled workers in tourism, construction, agriculture, and household 
work. Emigration is also critical as educated skilled workers leave for better opportunities.

Foreign investment would raise labor productivity. Domestic industries do not want foreign investment and successfully lobby the government. The result is a lack of the familiar multinational hotels or resorts, and lower wages. While quaint villages are part of the appeal of Greece, large multinational tourist operations could be isolated.

\section{Tourism and the Macroeconomics of Greece}

Discretionary macroeconomic policies are unavailable in the Euro Zone. The supervised balanced budget eliminates fiscal policy. The government has no control over the money supply due to the fixed exchange rate. Greece is a price taker in the international credit market. The euro "gold standard" exchange rate not subject to competitive devaluation or depreciation.

The crisis is due to government debt $\mathrm{D}$ growing to nearly double national income. Debt payments are based on the international interest rate $\mathrm{r}^{*}$. The government is borrowing to make interest payments $r^{*} \mathrm{D}$. The usual government budget constraint $\mathrm{G}+\mathrm{r}^{*} \mathrm{D}=\mathrm{T}+\Delta \mathrm{D}+\Delta \mathrm{M}$ is reduced to $\mathrm{G}+\mathrm{r}^{*} \mathrm{D}=\mathrm{T}$ where $\mathrm{G}$ is government spending, $\mathrm{T}$ tax revenue, and $\mathrm{M}$ the money supply.

Default would eliminate D. Default and return to the drachma would lead to the constraint $\mathrm{G}-\mathrm{T}=\Delta \mathrm{M}$ ensuring inflation and depreciation. The government could default and "euroize" facing the stark constraint $\mathrm{G}=\mathrm{T}$.

The banks are forced to loan deposits to the government. In 2015 the government closed the banks and introduced "capital control" limits on accounts designed to uncover cash transactions and increase tax revenue. Under threat of a "bail-in" taking of deposits, the government offered to waive ta penalties and interest on past undeclared income.

Figure 9 shows the recent history of the current account CA. The sharp decrease in 2005 was due to increased import spending and the subsequent turnaround during the crisis. Rising trade in services TS includes tourism revenue X Travel. The current account reached surplus in 2013.

The appreciating euro is thought to have lowered potential export revenue although the evidence is mixed. Dritsakis (2004) and Dritsakis and Gialetaki (2004) find drachma depreciation decreased tourism revenue from the EU. Thompson and Thompson (2010) find the euro switch raised tourism revenue, evidence of inelastic demand while Thompson (2013), Papanikos (2015b), and Cheng, Kim, and Thompson (2013) find depreciation raises tourism revenue. At any rate, the euro seems destined to persist as a strong currency. 
Figure 9. Balance of Payments

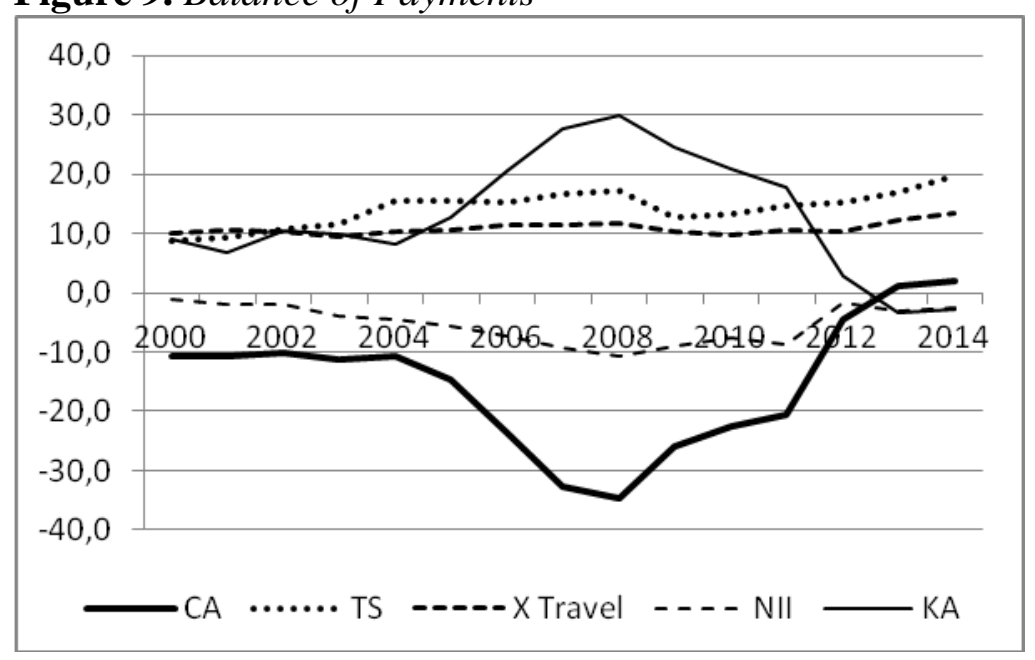

The capital account KA is a mirror image of the current account with investment inflows diminishing since 2008 and turning negative in 2013. Declining net investment income NII from 2000 reflects payments to increased foreign investment, trends that reversed during the crisis.

Figure 10 shows national income growing during the 1990s following a trend from the 1980s. The effect of the government crisis in 2009 is apparent with a slight recovery or at least stabilization starting in 2013.

Figure 10. National Income

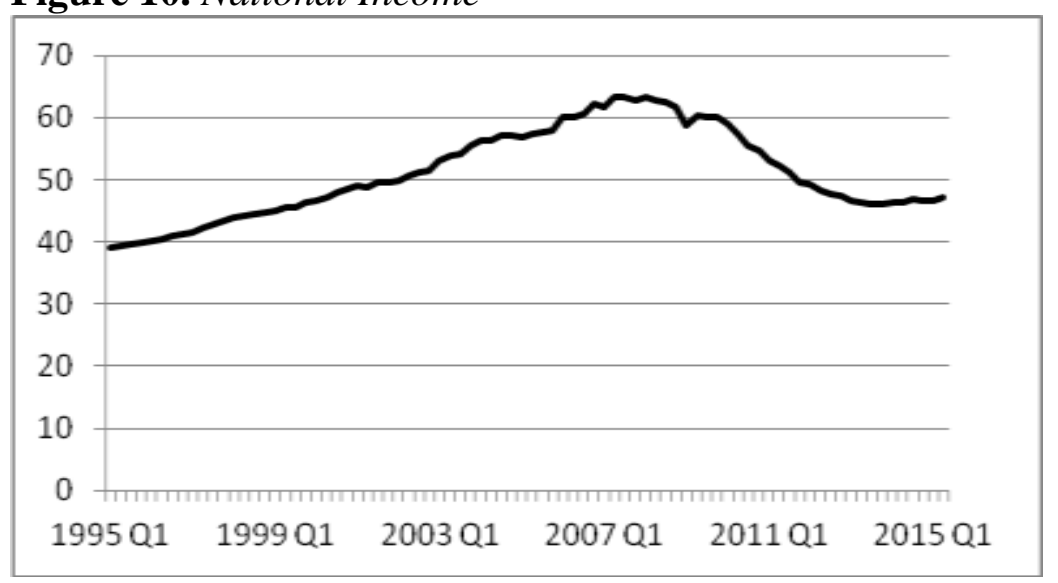

Figure 11 shows income per capita y has a less dramatic increase up to the crisis and much less of a decline during the early years. The empirical evidence on the link between tourism and growth is mixed. Dritsakis (2004) finds some evidence of a positive link. In panel data Alper (2014) finds similar positive evidence while Tugcu (2014) finds mixed evidence. In 2010 income per capita stabilized at $€ 14,000$ near the low end of developed countries. Thompson (2008) develops an economic growth model separating foreign capital and future payments. The only proven way to increase income per capita $\mathrm{y}$ is to 
raise the capital/labor ratio through investment. The government of Greece stands in the way of foreign investment with regulations and cronyism.

Figure 11. Income per Capita

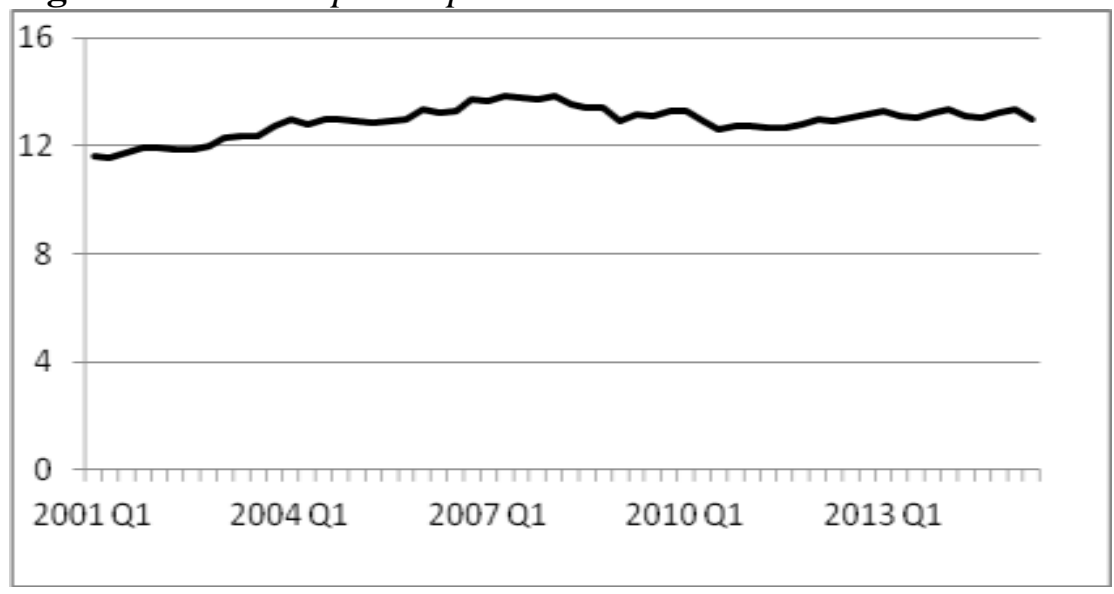

The pension system taxes workers for transfer to retirees. Reduced saving associated with the transfer lowers income, hurting both workers and retirees. Pension payments are about as large as the rest of government spending. During the crisis, payments have been reduced and the retirement age raised with the system forced to become more honest.

The spending shares in Figure 12 show components of national income. The consumption spending share $\mathrm{C} / \mathrm{Y}$ is constant at about $70 \%$. The crisis is apparent in the falling investment share I/Y that not only lowers income this year but slows growth. The government spending share G/Y has been constant. The import spending share $\mathrm{M} / \mathrm{Y}$ has also been constant while the export share $\mathrm{X} / \mathrm{Y}$ has grown. Falling prices have boosted export revenue in the classic pricespecie flow mechanism.

Figure 12. National Income Spending Shares

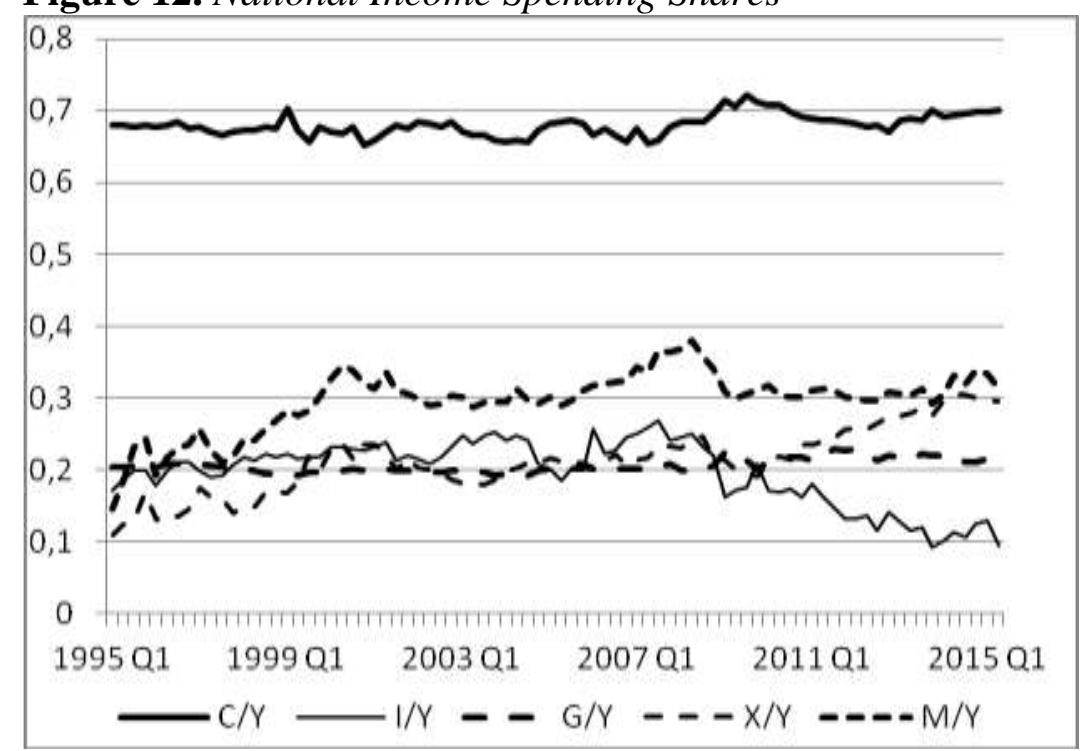


Eeckels, Filis, and Leon (2012) note relatively volatile cycle of tourism revenue in Greece contributes to income variation. While the shares in Figure 12 may appear consistent with this result, investment spending is much more volatile and more critically has been declining.

Figure 13 shows the share of tourism in national income. Open foreign investment would increase the share and national income. If tourism grows to $40 \%$ of income and half of that goes to property owners, that income might represent $5 \%$ of the value of the property. A property tax rate of $2.5 \%$ would generate tax revenue equal to $10 \%$ of national income. Property tax rates are presently under $0.5 \%$. Replacing inefficient sales and income taxes with property taxes would simplify collection and shift the tax burden toward foreign consumers and firms.

Figure 13. Tourism Revenue share of Income

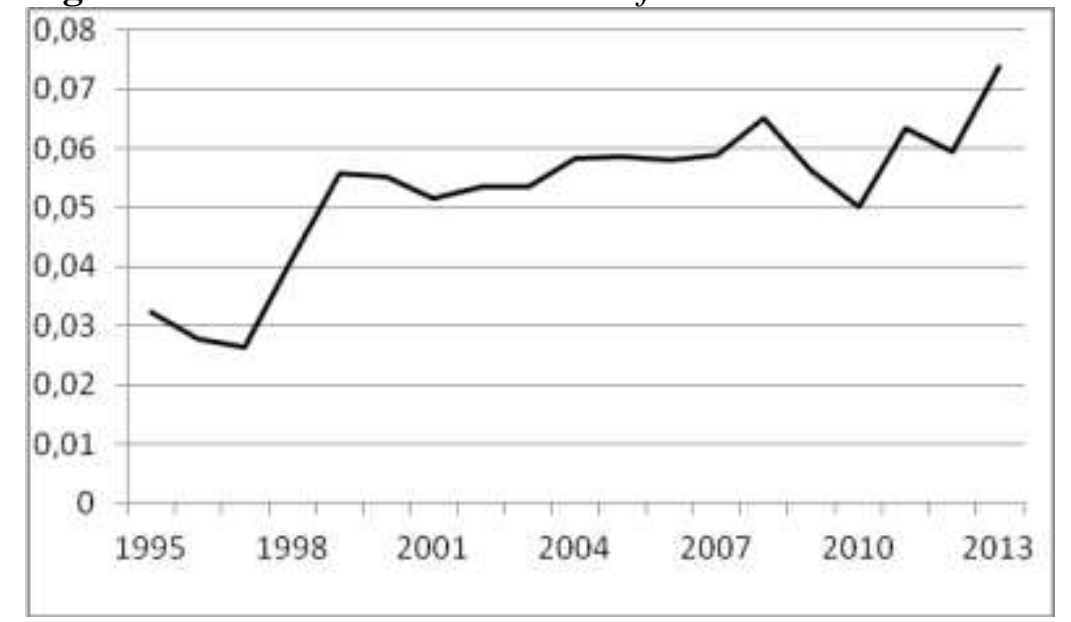

\section{Conclusion}

Tourism is a large growing industry offering Greece a market solution to its government debt crisis. Following the lead of tourism, increased specialization and trade would raise income and relieve the taxpayer burden of the debt. Taxing property instead of sales and income would increase efficiency.

The typical macroeconomic policies would have weak effects. Complaints over "austerity" suggest the crisis caused by government spending could be solved by government spending! Improving investment policy stands as the only option to raise income. Restrictions on foreign investment can be eliminated, the legal system simplified, corruption curtailed, and government operation streamlined. These will be difficult steps for a government that caters to vested interests.

Labor market reform is imperative. Labor laws can be modernized giving workers the choice of whether to join a union, the "open shop" giving employers incentive to share profit. Other fundamental reforms include eliminating job tenure and outlawing public sector strikes. 
Export industries other than tourism have potential to raise income. The government should let markets identify profitable opportunities. Industries unable to compete should be allowed to fail. Nationalized industries and monopolies should be privatized. As an example, the nationalized ports slowly degraded for decades before privatization has given them the opportunity to flourish. The evolving privatization of airports provides another example of inefficient government monopoly.

Banks should be relieved of the required purchase of government bonds. Banking restrictions or "capital controls" should be eliminated. The government should not have license to close banks. International banks should be allowed to compete. Sitting at the intersection of Europe and the Middle East, Greece has the potential to develop a first rate financial industry. The government seems to be pursuing economic collapse with the goal of nationalizing banks, a strategy advocated by a previous finance minister.

This list of reforms will require a ground shift in government with imbedded opposition hindering every step. The alternative of an Eastern bloc style has been tried in the region. Greece can take advantage of its long history of successful merchants to create a competitive economy with tourism leading the way.

\section{References}

Aslan, Alper (2014) Tourism development and economic growth in the Mediterranean countries: Evidence from panel Granger causality tests, Current Issues in Tourism 17, 363-72.

Cheng, Ka Ming, Hyeongwoo Kim, and Henry Thompson (2013) The real exchange rate and the balance of trade in US tourism, International Review of Economics and Finance (2013) 122-8.

Dritsakis, Nikolas (2004) Tourism as a long-run economic growth factor: An empirical investigation for Greece using causality analysis, Tourism Economics 10, 305-16.

Dritsakis, Nikolaos and Gialetaki, Katerina (2004) Cointegration analysis of tourism revenues by the member countries of European Union to Greece, Tourism Analysis 9, 179-88.

Eeckels, Bruno, George Filis, and Costas Leon (2012) Tourism income and economic growth in Greece: Empirical evidence from their cyclical components, Tourism Economics 18, 817-54.

Kasimati, Evangelia and Peter Dawson (2009) Assessing the impact of the 2004 Olympic Games on the Greek economy: A small macroeconometric model, Economic Modelling 26, 139-146.

Papanikos, Gregory (2015a) Taxing wealth and only wealth in an advanced economy with an oversized informal economy and vast tax evasion: The case of Greece, Vierteljahrshefte zur Wirtschaftsforschung 84, 85-106.

Papanikos, Gregory (2015b) The real exchange rate of euro and Greek economic growth, The Journal of Economic Asymmetries 12, 100-9.

Thompson, Alexi (2013) Greek tourism: Return to the drachma? Tourism Economics $19,1475-81$ 
Thompson, Alexi and Henry Thompson (2010) The exchange rate, euro switch, and tourism revenue in Greece, with Alexi Thompson, Tourism Economics 16, 773-6

Thompson, Henry (2008) Economic growth and foreign capital, Review of Development Economics x, 694-701

Thompson, Henry (2016) Tourism demand and wages in a general equilibrium model of production, Tourism Economics 22, 81-92

Tugcu, Can (2014) Tourism and economic growth nexus revisited: A panel causality analysis for the case of the Mediterranean Region, Tourism Management 42, 20712. 
